\title{
PENGARUH MODEL PEMBELAJARAN KOOPERATIF TIPE JIGSAW DENGAN PENDEKATAN PMR TERHADAP ASPEK AFEKTIF MATEMATIKA SISWA KELAS VIII SMP NEGERI DI KABUPATEN LAMPUNG UTARA
}

\author{
Karsoni Berta Dinata ${ }^{1}$ \\ ${ }^{1}$ Program Studi Pendidikan Matematika STKIP Muhammadiyah Kotabumi \\ email: karsoni.bertadinata@gmail.com
}

\begin{abstract}
The purpose of this study was to determine the effect of the jigsaw cooperative learning model with a realistic mathematics education (PMR) approach to students' affective aspects of mathematics. This type of research is quasi-experimental research. This study consisted of independent variable namely jigsaw cooperative learning model with realistic approach and one dependent variable namely the affective aspects of students' mathematics. The population in this study was the eighth grade students of State Junior High Schools in North Lampung Regency. Sampling was carried out by stratified cluster random sampling technique and obtained 9 classes from 3 state junior high schools in North Lampung Regency, consisting of 3 experimental classes I, 3 experimental classes II, and 3 control classes. The instrument for collecting data is a questionnaire on the affective aspects of mathematics, Testing the hypothesis in this study using a t-test. The results showed that there was an influence of the Jigsaw cooperative learning model with the PMR approach to the affective aspects of students' mathematics.
\end{abstract}

Keyword: Jigsaw, PMR Approach, and Affective Aspect

\section{PENDAHULUAN}

Matematika merupakan ilmu universal yang berguna bagi kehidupan manusia dan juga mendasari perkembangan teknologi modern, serta mempunyai peran penting dalam berbagai disiplin dan memajukan daya pikir manusia. Perkembangan pesat di bidang teknologi informasi dan komunikasi dewasa ini dilandasi oleh perkembangan matematika di bidang teori bilangan, aljabar, analisis, teori peluang, dan matematika diskrit. Untuk menguasai dan mencipta teknologi di masa depan, diperlukan penguasaan dan pemahaman atas matematika yang kuat sejak dini.

Mata pelajaran matematika diberikan di sekolah dasar dan menengah bertujuan agar siswa memiliki kemampuan di antaranya: memahami konsep matematika, menjelaskan keterkaitan antarkonsep dan mengaplikasikan konsep atau algoritme, secara luwes, akurat, efisien, dan tepat, dalam pemecahan masalah, serta memiliki sikap menghargai kegunaan matematika dalam kehidupan, yaitu memiliki rasa ingin tahu, perhatian, dan minat dalam 
mempelajari matematika, serta sikap ulet dan percaya diri dalam pemecahan masalah.

Dalam pelaksanaanya di lapangan, guru belum sepenuhnya menggunakan pendekatan dan metode yang bervariasi dalam proses pembelajaranya. Hasil penelitian Sadia, dkk dalam Muslich (2009:23) menemukan bahwa metode ceramah merupakan metode yang dominan (70\%) digunakan guru, sedangkan tingkat dominasi guru dalam interaksi belajar mengajar juga tinggi yaiu 67\%. Dengan demikian, siswa relatif pasif dalam pembelajaran. Begitu juga dalam pembelajaran matematika, kegiatan guru berceramah menunjukkan peningkatan, sementara interaksi guru-siswa, kegiatan siswa melakukan diskusi, eksplorasi, dan investigasi terkait gagasan-gagasan matematika menunjukkan penurunan (penelitian World Bank, tahun 2007 dan 2011).

Pembelajaran yang baik tidak hanya bertujuan untuk meningkatkan prestasi belajar siswa saja atau hasil belajar pada ranah kognitif saja, tetapi juga harus memperhatikan ketercapaian hasil belajar pada ranah afektif. Guru matematika tidak boleh menganggap bahwa yang terpenting adalah hasil belajar matematika yang lebih bersifat kognitif. Guru tidak boleh lupa bahwa keberhasilan atau kesuksesan seseorang sangat dipengaruhi oleh pandangan dan keyakinan seseorang yang diwujudkan dalam keseluruhan sikap. Menurut Budiyono (2015:133) kadar afektif seseorang akan sangat menentukan kehidupan seseorang dimasa mendatang. Oleh karena itu, hasil belajar matematika tidak hanya bertujuan pada ranah kognitif saja dalam hal ini prestasi belajar matematika, tetapi juga harus mengejar hasil belajar pada ranah afektif. Penelitian yang dilakukan oleh Ignacio et al. (2006) menyatakan bahwa adanya keberadaan domain afektif siswa dalam pengaruhnya terhadap motivasi dan harapan mereka dalam mencapai kesuksesanya, khususnya dalam penguasaan konsep matematika.

Pendekatan yang dipilih dalam suatu model pembelajaran sangat penting. Menurut Muslih (2009:40) ada dua hal mengapa pendekatan dalam suatu pembelajaran dirasa cukup penting. Pertama, penentuan isi program, materi pembelajaran, strategi pembelajaran, sumber belajar, dan teknik/bentuk penilaian harus dijiwai oleh pendekatan yang dipilih. Kedua, salah satu acuan untuk menentukan keseluruhan tahapan pengelolaan pembelajaran adalah pendekatan yang dipilih. Oleh karena itu, pendekatan dalam model pembelajaran merupakan komponen yang penting karena ikut menentukan keberhasilan tercapainya tujuan pembelajaran.

Menurut Soejadi (2000:13) salah satu karakteristik dalam matematika adalah memiliki objek kajian yang abstrak. 
Seorang guru matematika harus berusaha untuk mengurangi sifat abstrak dari dari objek matematika itu sehingga memudahkan siswa menangkap pelajaran matematika. Hal ini berarti pendekatan yang digunakan adalah pendekatan yang mampu mendekatkan matematika ke dalam dunia siswa. Salah satu Pendekatan yang digunakan adalah pendekatan pendidikan matematika realistik (PMR).

Pendekatan PMR dilandasi oleh pandangan tentang posisi matematika sebagai suatu bagian dalam kehidupan manusia. Matematika bukanlah suatu ilmu yang terisolisolasi dari kehidupan dari kehidupan manusia hanya karena karakteristik yang dimilikinya. Matematika adalah suatu ilmu pengetahuan yang menjadi bagian dari kehidupan manusia. Freudenthal dalam Wijaya (2012:20) menyatakan bahwa mathematics is a human activity.

Jigsaw merupakan salah satu jenis dari model pembelajaran koperatif yang mempunyai ciri-ciri utama. Menurut Eggen \& Kauchak (2012:137) Jigsaw mempunyai dua ciri utama. Pertama, Jigsaw dirancang untuk mengajarkan bangunan pengetahuan sistematis, dimana satu topik terdiri dari berbagai konsep atau fakta. Kedua, Jigsaw mencakup elemen spesialisasi tugas. Dalam hal ini, siswa terspesialisasi dalam tugas yang diberikan kepadanya dan mengajarkan pemahamanya kepada temannya.
Pada Jigsaw, siswa bekerja dalam kelompok-kelompok yang beragam. Para siswa diberikan tugas untuk mempelajari suatu materi dan menjadi "seorang ahli" dari suatu topik yang berbeda untuk setiap anggota kelompok. Setelah setiap siswa mempelajari materinya, para siswa dari kelompok yang berbeda dengan topik yang sama berjumpa pada kelompok ahli untuk mendiskusikan topik mereka. Seorang ahli tersebut kemudian kembali pada kelompoknya masing-masing dan kemudian secara bergilir mengajarkan pada rekan satu timnya tentang topik yang dikuasainya. Pada akhirnya, para siswa terlihat mampu menguasai semua topik dan skor kuis menjadi skor kelompok. Skor yang dikontribusikan pada pada timnya didasarkan pada sistem kemajuan dan kemudian diberikan suatu penghargaan. Hal tersebut menjadikan para siswa termotivasi untuk mempelajari dengan sungguh-sungguh materi-materi tersebut dan untuk bekerja sungguhsungguh dalam kelompok ahli sehingga mereka dapat membantu kelompoknya melakukanya dengan baik.

Dalam penelitian ini dikombinasikan model pembelajaran kooperatif yang menekankan kontruksi pengetahuan siswa melalui aspek sosial antarsiswa dalam satu kelompok yang heterogen dan dengan pendekatan PMR. Kombinasi model pembelajaran kooperatif dengan pendekatan 
PMR diharapkan mampu memudahkan siswa dalam mencapai tujuan pembelajaran.

Ranah afektif menurut Anderson dan Gable dalam Budiyono (2015:134) adalah kualitas yang menunjukan cara khas seseorang menyatakan perasaan atau mengungkapkan emosinya. Jadi, berdasarkan pendapat Anderson dan Gable dapat dikatakan bahwa ada beberapa karakteristik yang terkait dengan aspek afektif, yaitu pertama, harus melibatkan perasaan dan emosi siswa. Kedua, harus bersifat khas, artinya aspek afektif dari setiap individu/siswa mempunyai ciri atau keunikan masing-masing.

Aspek afektif adalah suatu aspek pada diri siswa mengenai sikap, minat, nilai, konsep diri dan moral yang dapat dilihat pada saat proses pembelajaran matematika dan hasilnya menunjukan kemauan siswa yang positif atau negatif dalam bertindak.

Adapun untuk menentukan masingmasing indikator pada aspek afektif sebagai berikut.

\section{a. Sikap}

1) Membaca buku matematika.

2) Mempelajari matematika.

3) Melakukan interaksi dengan guru metematika.

4) Mengerjakan tugas matematika.

5) Melakukan diskusi tentang matematika. b. Minat

1) Memiliki catatan pelajaran matematika.

2) Berusaha memahami matematika.

3) Memiliki buku matematika.

4) Mengikuti pelajaran matematika.

c. Konsep diri

1) Memilih mata pelajaran yang mudah dipahami.

2) Memiliki kecepatan memahami mata pelajaran.

3) Menunjukkan mata pelajaran yang dianggap sulit.

d. Nilai

1) Memiliki keyakinan akan peran sekolah.

2) Meyakini keberhasilan diri pada siswa.

3) Menunjukan keyakinan atas kemampuan guru.

4) Mempertahankan keyakinan akan harapan masyarakat.

e. Moral

1) Memegang janji.

2) Memiliki kepedulian terhadap orang lain.

\section{METODE}

Jenis penelitian ini merupakan penelitian eksperimental dengan desain posttest only group desain. Populasi penelitian ini adalah seluruh siswa kelas VIII SMP Negeri se-Kabupaten Lampung Utara, dengan pengambilan sampel meng- 
gunakan teknik stratified cluster random sampling. Sampel yang diperoleh, yaitu siswa kelas VIII SMP Negeri 1 Abung Selatan untuk kategori sekolah tinggi, SMP Negeri 2 Abung Selatan untuk kategori sekolah sedang, dan SMP Negeri 4 Kotabumi untuk kategori sekolah rendah.

Variabel terikat dalam penelitian ini yaitu aspek afektif matematika, sedangkan variabel bebasnya yaitu model pembelajaran kooperatif tipe jigsaw. Teknik pengumpulan data yang digunakan dalam penelitian ini yaitu metode angket. Metode angket digunakan untuk mengukur aspek afektif matematika. Setelah dilakukan perlakuan, angket aspek afektif matematika diberikan kepada siswa untuk memperoleh data penelitian.

Instrumen angket yang digunakan dalam penelitian terlebih dahulu dilakukan validasi isi, uji konsistensi internal/daya pembeda, dan uji reliabilitas untuk mengetahui kelayakan butir soal tes atau angket. Uji hipotesis penelitian dilakukan dengan uji-t. Untuk uji prasyarat sebelum uji hipotesis mencakup uji normalitas univariat dengan uji Liliefors', selanjutnya dilakukan uji homogenitas variansi dengan menggunakan uji-F.

\section{HASIL DAN PEMBAHASAN}

Sebelum instrumen angket diujikan dilakukan terlebih dahulu penilaian dari para ahli atau validitas isi. Pengujian validitas isi dilakukan oleh satu orang dosen program studi pendidikan Bimbingan Konseling (BK) FKIP Universitas Sebelas Maret Surakarta, yaitu Dr. Asrowi, M.Pd., satu dosen Universitas Muhammadiyah Surakarta Program Studi Psikologi Fakultas Psikologi, yaitu Rini Lestari, S. Psi, M.Psi, serta satu dosen STKIP Muhammadiyah Kotabumi, yaitu Dr. Badawi. Angket aspek afektif matematika siswa yang diajukan kepada validator terdiri dari 60 butir pernyataan. Pada saat pengajuan angket aspek afektif kepada para validator, terdapat beberapa saran perbaikan yang harus dilakukan. Validator pertama memberikan catatan berupa pertanyaan dari beberapa item soal agar dapat diupayakan untuk memotivasi belajar matematika siswa, serta menggunakan kalimat yang disesuaikan dengan kemampuan siswa SMP. Hal tersebut dikarenakan terdapat pernyataan yang memuat istilah asing pada beberapa item soal. Validator kedua memberikan saran agar membuat pernyataan yang tidak bermakna ganda dan dengan bahasa yang mudah dipahami, serta dikaitkan setiap pernyataan dengan matematika.Validator ketiga memberikan perbaikan dalam petunjuk pengisian angket, kemudian memberikan perbaikan pada beberapa butir soal yang dianggap masih menggunakan bahasa yang kurang jelas, kurang komunikatif, dan sulit dipahami sehingga perlu diperbaiki agar bahasanya baik dan mudah dipahami 
untuk siswa SMP. Setelah dilakukan perbaikan pada instrumen angket, peneliti mengajukan kembali angket Aspek afektif kepada validator ketiga untuk melihat setiap item angket yang telah diperbaiki. Kesimpulan dari validator tersebut adalah semua item soal dinyatakan valid secara isi sesuai kriteria yang telah ditentukan.

Penetapan hasil ujicoba angket aspek afektif dilakukan setelah dilakukan analisis butir instrumen terhadap konsistensi internal. Dari 60 butir pernyataan diambil 40 butir dengan konsistensi internal yang baik. Sehingga 40 butir angket aspek afektif dapat digunakan sebagai instrumen dalam penelitian ini

Uji reliabilitas angket aspek afektif matematika siswa pada penelitian ini menggunakan rumus Alpha dari Cronbach. Pengujian reliabilitas dilakukan pada butir angket yang terpilih, yaitu pada 40 butir pernyataan. Berdasarkan hasil pengujian yang dilakukan dengan program Ms.Excel, diperoleh $r_{11}=0,836$ yang dapat diinterpretasikan bahwa angket aspek afektif reliabel karena $r_{11} \geq 0,70$.

Analisis data hasil penelitian dilakukan dengan uji t. Berikut data hasil penelitian disajikan dalam Tabel 1.

Tabel 1

Rangkuman Data Hasil Penelitian

\begin{tabular}{|l|c|c|c|}
\hline Kelompok & $\begin{array}{c}\text { Jumlah } \\
\text { siswa }\end{array}$ & Rerata & Varians \\
\hline Ekperimen & 85 & 128 & 238,9 \\
\hline Kontrol & 86 & 113 & 147,1 \\
\hline
\end{tabular}

Sebelum dilakukan analisis uji-t dilakukan terlebih dahulu uji normalitas dengan menggunakan uji liliefors. Berikut hasil analisis uji normalitas data hasil penelitian dengan menggunakan uji liliefor's disajikan dalam Tabel 2 berikut.

Tabel 2

Rangkuman Hasil Uji Normalitas

\begin{tabular}{|l|c|c|}
\hline Kelompok & Ltabel & \multicolumn{1}{c|}{ Lhitung } \\
\hline Ekperimen & 0.0961 & 0.0853 \\
\hline Kontrol & 0.0961 & 0.0706 \\
\hline
\end{tabular}

Dengan membandingkan L hasil perhitungan dengan $\mathrm{L}$ tabel diperoleh bahwa kedua kelompok berdistribusi normal. Adapun hasil perhitungan uji homogenitas menggunakan uji-F diperoleh $\mathrm{F}_{\text {hitung }}=1,67$. Untuk nilai $\mathrm{F}$ tabel yaitu 1,75. Dengan demikian disimpulkan bahwa kedua kelas homogen. Karena kedua persyratan uji-t yaitu uji normalitas dan uji homogenitas telah terpenuhi maka uji-t bisa dilanjutkan.

Berdasarkan hasil perhitungan diperoleh $t_{\text {hitung }}=2,27$ dan $t_{\text {tabel }}$ untuk $\mathrm{dk}$ 169 dan $\alpha=0.05$ diperoleh sebesar 1,98. Dengan demikian, disimpulkan secara statistik bahwa ada pengaruh model pembelajaran kooperatif tipe jigsaw dengan pendekatan PMR terhadap aspek afektif matematika siswa.

\section{PENUTUP}

Perbaikan mutu pembelajaran hendaknya selalu dilakukan secara terus 
menerus dan berkelanjutan. Mutu pem- dilakukan untuk meningkatkan aspek belajaran dapat dilihat dari hasil belajar. afektif siswa adalah dengan menggunakan Hasil belajar tidak hanya aspek kognitif model pembelajaran kooperatif tipe jigsaw saja, tetapi juga dapat dilihat dari aspek dengan pendekatan PMR. afektif. Salah satu upaya yang bisa

\section{DAFTAR RUJUKAN}

Budiyono. 2015. Pengantar Penilaian Hasil Belajar. Surakarta: Universitas Sebelas Maret Press.

Eggen, P. and Kauchak, D. 2012. Strategi dan Model Pembelajaran (Mengajarkan Konten dan Keterampilan Berpikir). Edisi Keenam. Jakarta: Indeks.

Ignacio, N. G., Nieto, L. J. B., and Barona, E. G. 2006. The Affective Domain in Mathematics Learning. International Electronic Journal of Mathematics Education, vol. 1, no. 1, hlm. 16-30.

Muslich, M. 2009. KTSP Pembelajaran Berbasis Kompetensi dan Kontekstual. Jakarta: Bumi Aksara.

Soedjadi, R. 2000. Kiat Pendidikan Matematika Di Indonesia, Konstatasi Keadaan Masa Kini Menuju Harapan Masa Depan. Jakarta. Dirjen Dikti Departemen Pendidikan Nasional. 